\title{
The Relationship between Leadership Style and Conflict Management among Nurses in Educational and Health Centers
}

\author{
Zahra Marzieh Hassanian¹, Amir Sadeghi², Maryam Farhadi³, Amanj Rahrovan ${ }^{4}$ \\ ${ }^{1}$ Department of Nursing, School of Nursing and Midwifery, Hamadan University of Medical Sciences, \\ Hamadan, Iran \\ ${ }^{2}$ Research Center for Maternal and Child Care, Hamadan University of Medical Sciences, Hamadan, Iran \\ ${ }^{3}$ Modeling of Non-Communicable Diseases Research Center, Hamadan University of Medical Sciences, \\ Hamadan, Iran \\ ${ }^{4}$ Bu-Ali Hospital, Marivan County, Kurdistan, Iran
}

\section{SUMMARY}

Leadership is a tool and a potential power in an organization. Managers would be able to achieve organizational goals and also manage conflicts in a more effective manner by using appropriate leadership styles. The purpose of this study was to investigate the relationship between leadership styles and conflict management among the nurses of Hamadan City's educational and health centers.

This study was carried out utilizing a descriptive and correlational procedure. Using the stratified random sampling method in this study, 240 nurses were selected from educational and health centers. Two standard questionnaires were used for gathering data regarding leadership style and conflict management. The data were analyzed using SPSS software version 16 and by employing statistical tests such as Pearson's correlation coefficient and Kruskal-Wallis test.

The most common leadership style observed in the nurses was the democratic type $(94.6 \%)$, while the directive style and the combined approach was preferred by only 2.5 and $2.9 \%$, respectively. Moreover, the most preferred strategy of conflict management was non-intervention $(50.15 \pm 10.34)$, followed by the solution-oriented $(38.65 \pm 7.31)$ and control (27.04 \pm 3.61$)$ strategies. A significant relationship between the leadership style attribute and the conflict management strategy was found ( $\mathrm{p}<$ 0.001).

It was found that leadership style is significantly and positively correlated with the solution-oriented and nonintervention strategies of conflict management. In contrast, the relationship between leadership style and control strategy is not significant. Adoption of the democratic leadership style and the combined strategy is recommended for nursing managers in the field of conflict management.

Key words: leadership style, conflict management, nurse, clinical and educational centers 
Original article

Corresponding author:

Amanj Rahrovan

Email:amanj.mardin.nursing1392@gmail.com 


\section{INTRODUCTION}

Nurses work with an astonishing range of characters, so they ought to study leadership and learn to work well and effectively, with other than just clients, such as clients' families, physicians, psychologists, physical therapists and social workers (1). Generally, the organizational structure in hospitals has been noticeably bureaucratic, with a few decision makers and many groups of workers. It is expected that nurse leaders develop the quality of care and proficient and effective nursing processes which agree with standards and assist in the progress of individual and organizational culture (2). Leadership is acknowledged and encouraged in the nursing profession. Leaders ought to lead, and their behavioral style is dependent on the duties of the subordinates and many other variables (3). The Fiedler theory on relationship-oriented and task-oriented styles of leadership offers no preferred style, but rather situations in which one style or the other is more effective (4). Fiedler recommends that leadership effectiveness is an interface between the style and the extent to which the statuses allow the leader's effect (5). The contingency theory is a normal result of the situational theory (6) -issues of the situation comprise the official and unofficial authority of the leader, the relationship between the leader and the followers, as well as the nature of the duty or aim (7).

Academicians, nurse clinicians, and researchers are confronted with many challenges and need to adjust their leadership styles to match the unique challenges necessitated by diverse roles and the institution. Healthcare leaders are truly challenged by differing priorities, quickly changing societies, requirements, insufficient assets, and changes in the healthcare system. Nursing leaders are responsible for knowledgeable nursing practices. Medical science is primarily a rich area of knowledge whose profundity is not amply used to satisfy the patient's desires and therefore does not produce significant influence on health outcomes (8). These circumstances and the ambiguity joined with the growing obstacles in the patient-care setting produce many conditions for conflict. According to a study of the Management Association, nursing managers usually allocate $20 \%$ of their assigned time to conflict management within the nursing organization (3).

Conflict is a regular reality and it can restrict work from being done, moreover, severe conflicts can be very stressful. In some occasions, conflict is looked upon as a bad thing, but a healthy amount of debate and discussion can lead to the best possible consequences and great notions are habitually borne from such exchanges. Conflict management notes that individuals manifest stable and persistent action when conflict arises (9). Specific content is used to complete conflicts (conflict management) and inspire shared understanding to create an environment in which individuals can present their best attempts (10). Effective management is measured by how well the leader manages real world challenges on a regular basis (3). Considering the importance of leadership style and its relationship with conflict management, the present study was set to investigate the relationship between leadership style and conflict management in nurses who were working in the educational/health centers of Hamadan University of Medical Sciences.

\section{MATERIALS AND METHODS}

\section{Design/Setting}

This study is a descriptive and correlational research. The population included all the nurses in the educational, health and treatment centers of Hamadan University of Medical Sciences.

\section{Sample size and data collection}

The sample consisted of 240 nurses, selected via stratified random sampling. The inclusion criteria for the samples were having a bachelor's degree or higher in nursing and a minimum of two years of work experience, while the exclusion criteria were not completing or not returning the forms.

\section{Instrument}

The leadership style questionnaire contained 18 questions with eight possible answers in a spectrum. A score higher than 64 demonstrated the democratic leadership style, a score lower than 57 denoted the directive leadership style, and a score between 58 and 63 denoted the combined approach. The conflict management questionnaire contained 30 questions and measured three types of conflict management strategies, i.e., the avoiding strategy, the solution-oriented strategy and the control strategy. All questions of this questionnaire were estimated by the seven point Likert scale. It should be noted that the items 10, 21, 22, and 23 of this questionnaire were reciprocal questions.

The validity of the leadership style questionnaire of this study was approved by a panel of experts 
consisting of professors of the Nursing and Midwifery Faculty. In this study, the reliability of the leadership style questionnaire was confirmed through Cronbach's alpha and stood at 86.0. Moreover, the validity of the conflict management questionnaire was also approved by the Panel of Experts from the Nursing and Midwifery faculty. The reliability of the conflict management questionnaire in this study was confirmed through the Cronbach's alpha, which was estimated at 0.73 .

\section{Data analysis}

In the present study, descriptive and inferential statistics were used to evaluate data. SPSS software package version 16 was used for performing statistical tests. Ethical issues were considered in all steps of the study. P value less than 0.05 was considered statistically significant.

\section{RESULTS}

The mean age of nurses who participated in the present study was 43.39 years with a standard deviation of 9.43 , ranging from 23 to 58 years of age, of which $75.8 \%$ were females and $24.2 \%$ males. Moreover, $78.8 \%$ of them had a bachelor's degree, while others $(21.2 \%$ were Masters of Science graduate. Furthermore, $53.8 \%$ of participants had an experience equal to or lower than nine years, while $12 \%$ had 21 years of experience, or higher. The experience of the nurses who participated in the present study ranged from 2 to 30 years. The majority of the nurses $(65 \%)$ were married, whereas $35 \%$ were single.

The most preferred of the leadership styles of managers from the nurses' viewpoints was the democratic style with mean STD $86.92 \pm 16.76$, while the preferred style for conflict management from the nurses' viewpoints was the directive style $-50.45 \pm 7.62$ (Table 1 ).

The mean and STD of the scores in the control strategy was $27.04 \pm 3.61$, and the mean and STD of the solution-oriented strategy was $38.66 \pm 7.31$; the mean and standard deviation in the non-competition conflict management strategy was $50.15 \pm 10.34$ (Table 2).

In order to determine the relationship between leadership style and conflict management strategies (control, solution-oriented and non-competitive), the Pearson's correlation coefficient was used. The results showed that there is a positive linear relationship between leadership style and conflict management $(\mathrm{p}<0.001)$. There was a positive and significant relationship between the leadership style and non-competition conflict management in all categories.

The results of the findings showed that in the control management of the conflict management strategy, the highest mean and STD (of $27.67 \pm 2.98$ ) belonged to the directive leadership style; the lowest values were obtained for the combined leadership style with STD of $25 / 28 \pm 3.25$. The results of Kruskal-Wallis tests did not show a significant statistical difference in the mean scores of conflict management control at different levels of leadership style $(p=0.41)$.

In the solution-oriented conflict management strategy, the highest mean and STD, $38.88 \pm 5.71$, was obtained for the democratic leadership style; the lowest values were recorded for the combined leadership style, $33.71 \pm 5.71$. The results of Kruskal-Wallis tests did not show a significant statistical difference in the mean scores of solution-oriented conflict management at different levels of leadership style $(p=0.083)$.

In the non-intervention of conflict management strategy, the highest mean and STD $50.37 \pm 10.31$ were seen with the democratic leadership style; the lowest values were observed with the combined leadership style $43.14 \pm 11.52$. The results of Kruskal-Wallis tests did not show a significant statistical difference in the mean scores of non-intervention conflict management at different levels of leadership style $(p=0.249)$ (Table 4$)$.

Table 1. The descriptive statistics associated with various leadership styles from the viewpoint of nurses

\begin{tabular}{ccccccc}
\hline \hline Leadership style & Number & Percent & $\begin{array}{c}\text { Maximum } \\
\text { score }\end{array}$ & $\begin{array}{c}\text { Minimum } \\
\text { score }\end{array}$ & Mean & STD \\
\hline Directive style & 6 & 2.5 & 57 & 39 & 50.45 & 7.62 \\
Combined style & 7 & 2.9 & 63 & 58 & 60.60 & 3.3 \\
Democratic style & 227 & 94.6 & 124 & 64 & 86.92 & 16.76 \\
\hline \hline
\end{tabular}


Table 2. Descriptive statistics associated with various conflict management strategies

\begin{tabular}{ccccc}
\hline \hline $\begin{array}{c}\text { Conflict } \\
\text { management } \\
\text { strategy }\end{array}$ & Mean \pm STD & $\begin{array}{c}\text { Min } \\
\text { value }\end{array}$ & Max value & $\begin{array}{c}\text { Number of } \\
\text { items }\end{array}$ \\
\hline Control & $27.04 \pm 3.61$ & 35 & 21 & 7 \\
Solution oriented & $38.65 \pm 7.31$ & 52 & 27 & 11 \\
Non-intervention & $50.15 \pm 10.34$ & 65 & 28 & 12 \\
\hline \hline
\end{tabular}

Table 3. The relationship between leadership styles and conflict management strategies

\begin{tabular}{|c|c|c|c|c|c|c|c|c|}
\hline \multirow{3}{*}{$\begin{array}{l}\text { Leadership } \\
\text { style }\end{array}$} & \multicolumn{8}{|c|}{ Conflict management strategy } \\
\hline & \multicolumn{2}{|c|}{ Control } & \multicolumn{2}{|c|}{ Solution-oriented } & \multicolumn{2}{|c|}{ Non-competitive } & \multicolumn{2}{|c|}{ Conflict management } \\
\hline & $\begin{array}{l}\text { Number } \\
\text { (percent) }\end{array}$ & $\begin{array}{l}\text { Relation- } \\
\text { ship }\end{array}$ & $\begin{array}{l}\text { Number } \\
\text { (percent) }\end{array}$ & $\begin{array}{l}\text { Relation- } \\
\text { ship }\end{array}$ & $\begin{array}{l}\text { Number } \\
\text { (percent) }\end{array}$ & $\begin{array}{l}\text { Relation- } \\
\text { ship }\end{array}$ & $\begin{array}{l}\text { Number } \\
\text { (percent) }\end{array}$ & $\begin{array}{l}\text { Relation- } \\
\text { ship }\end{array}$ \\
\hline Directive & $\begin{array}{c}150 \\
(62.5)\end{array}$ & $\begin{array}{l}R=0.480 \\
P<0.001\end{array}$ & $30(12.5)$ & $\begin{array}{l}\mathrm{R}=0.048 \\
\mathrm{P}<0.462\end{array}$ & $60(25)$ & $\begin{array}{l}R=0.229 \\
P<0.001\end{array}$ & $240(100)$ & $\begin{array}{l}\mathrm{R}=0.225 \\
\mathrm{P}<0.001\end{array}$ \\
\hline Democratic & $\begin{array}{c}33 \\
(13.75)\end{array}$ & $\begin{array}{l}R=-0.51 \\
P<0.435\end{array}$ & $160(66.6)$ & $\begin{array}{l}R=0.198 \\
P<0.002\end{array}$ & 47 (19.6) & $\begin{array}{l}R=0.210 \\
P<0.001\end{array}$ & $240(100)$ & $\begin{array}{l}R=0.213 \\
P<0.001\end{array}$ \\
\hline Combined & $57(23.7)$ & $\begin{array}{l}R=0.048 \\
P<0.462\end{array}$ & $50(20.73)$ & $\begin{array}{l}R=0.176 \\
P<0.006\end{array}$ & $133(55.4)$ & $\begin{array}{l}R=0.229 \\
P<0.002\end{array}$ & $240(100)$ & $\begin{array}{l}R=0.210 \\
P<0.001\end{array}$ \\
\hline Total & $240(100)$ & $\begin{array}{l}R=0.048 \\
P<0.462\end{array}$ & $240(100)$ & $\begin{array}{l}R=0.176 \\
P<0.006\end{array}$ & $240(100)$ & $\begin{array}{l}\mathrm{R}=0.229 \\
\mathrm{P}<0.001\end{array}$ & $240(100)$ & $\begin{array}{l}R=0.213 \\
P<0.001\end{array}$ \\
\hline
\end{tabular}

Table 4. Comparison of scores associated with various conflict management strategies at different levels of leadership style

\begin{tabular}{ccccc}
\hline \hline $\begin{array}{c}\text { Conflict } \\
\text { management } \\
\text { strategy }\end{array}$ & Leadership style & Number & $\begin{array}{c}\text { Mean } \pm \\
\text { STD }\end{array}$ & $\begin{array}{c}\text { p-value based on the } \\
\text { Kruskal-Wallis test }\end{array}$ \\
\hline \multirow{2}{*}{ Control } & Directive & 6 & $27.67 \pm 2.98$ & \\
& Combined & 7 & $25.28 \pm 3.25$ & 0.41 \\
Solution- & Democratic & 227 & $27.07 \pm 3.61$ & \\
oriented & Directive & 6 & $35.17 \pm 7.63$ & \multirow{2}{*}{0.083} \\
& Combined & 7 & $33.71 \pm 5.71$ & \\
Non- & Democratic & 227 & $38.88 \pm 5.71$ & 0.249 \\
intervention & Directive & 6 & $50.00 \pm 8.65$ & \\
& Combined & 7 & $43.14 \pm 11.52$ & \\
\hline \hline
\end{tabular}

\section{DISCUSSION}

Most participants were aged below 31 years of age. Moreover, most participants were female; a small percentage of participants were master graduates and most of them were Bachelors in Nursing. Furthermore, a large number of participants had less than nine years of experience, while some had greater experience in nursing.

The most prevalent leadership style observed in the nurses was the democratic style, while the directive and combined styles were less observed. Nurses play a 
significant role in the improvement of health care and treatment of patients. Madathil et al. showed that transformational leadership was used by nurse managers (11). Akbari et al. demonstrated that most participants preferred to apply the directive style, and least used was the independent social style of leadership (12).

In the present study, we found that the nonintervention strategy was the most prevalent in the three strategies of conflict management. It can be inferred that most nurses were likely to avoid any competition in their handling of conflicts. Recent studies on conflict management have explained that the processes adopted for managing conflicts are complex and inconsistent, and selecting an approach can affect the consequence of conflicts.

In this study, there was a significant relationship between leadership styles and conflict management, however, no relationship was seen between the directive leadership style and the solution-oriented strategy, between the democratic leadership style and the control strategy, and between the combined leadership style and the control strategy. Adopting conflict management strategies would improve the quality of management and would help in achieving their goals. The relationship between leadership styles with the solutionoriented strategy and leadership style with the nonintervention strategy were significantly positive. There was a weak negative relationship between the democratic leadership style and the control strategy for conflict management; however, this relationship was not strong enough to be significant. A study showed that nurses utilized avoiding, collaborating, and compromising strategies for managing their conflicts (13).

It was further observed that the democratic leadership style had a lower tendency toward controlling conflicts. In contrast, managers who adopt the directive leadership style are more likely to use the control strategy for managing conflicts. Every leadership style can have a particular effect on conflict management. In another similar study, there was no significant relationship between leadership style and profession independence (14). The medical community currently requires empowerment throughout their education (15). Moreover leadership styles can influence nurses' per- formances both negatively and positively, which can affect the health and safety of patients indirectly. Nursing management adopts various leadership styles and conflict management strategies. However, most managers tend to adopt the democratic leadership style and use the solution-oriented strategy for managing conflicts, solving daily challenges, and achieving the organizational goals.

\section{CONCLUSION}

Nurse managers with the democratic leadership style prefer to use solution-oriented and nonintervention strategies for managing conflict in their organizations. In contrast, managers with the directive leadership style are more inclined to the control strategy. Considering that the non-intervention strategy was the most preferred form for managing conflicts, it is recommended that the democratic leadership style or the combined style for managing conflict be adopted. The democratic leadership style is the most appropriate approach that should be adopted and preserved for long-term solution of nursing problems and managing conflicts.

\section{Acknowledgement}

This article is part of the approved Nursing Master's thesis with the number 9406313508 of Hamadan University of Medical Sciences, which is approved at the Ethics Committee on Research Affairs in Hamadan University of Medical Sciences by IR.UMSHA.REC, 1394.288 code. The researchers thank the University Vice-Chancellor for Research, all the officials who participated in the approval and implementation of this project.

\section{Financial disclosure}

There is no financial interest.

\section{Competing interests}

No competing interests exist. 


\section{References}

1. Whitehead DK, Weiss S A, Tappen R M. Essentials of nursing leadership and management. $5 \mathrm{Ed}$. Philadelphia: Davis; 2010.

2. Feldman HR, Jaffe-Ruiz M, McClure ML, Greenberg M J, Smith T D, Janice M N, et al. Nursing Leadership: a concise encyclopedia. New York: Springer; 2008.

3. Forman H. Nursing leadership for patient-centered care: authenticity, presence, intuition, expertise. New York: Springer; 2011.

4. Marshall ES. Transformational leadership in nursing. New York:Springer; 2011.

5. Fiedler FE. Situational control and a dynamic theory of leadership. Leadership: Classical, contemporary, and critical approaches. UK: Oxford; 1997.

6. Laschinger H, Wong C, Regan S, Young-Ritchie C, Bushell P. Workplace incivility and new gradate nurses' mental health: The protective role of incivility. J NursAdm2013; 43(7/8):415-21.

https://doi.org/10.1097/NNA.0b013e31829d61c6

7. Weiss S A, Tappen R M. Essentials of Nursing Leadership and Management. Philadelphia: Davis; 2015.

8. Hassanian ZM, Ahanchian MR, Karimi-Moonaghi H. Canknowledge management be implemented in the teaching ofmedical sciences? ActaFac Med Naiss 2015; 32(4):231-42.

https://doi.org/10.1515/afmnai-2015-0024

9. Hosseini M, Azimzadeh E. Correlation between self-efficacy and nurses' conflict management strategies. JHPM 2013; 2(4):16-23.
10. Hassanin ZM, Bagheri A, Sadeghi A, MoghimBeighi A. Nurses' Social Responsibility and its Relationshipwith Their Demographic Profiles. Scientific Journal of Hamadan Nursing \& Midwifery Faculty 2017; 25(2):45-53.

https://doi.org/10.21859/nmj-25026

11. Madathil R, Heck NC, Schuldberg D. Burnout in Psychiatric Nursing: Examining the Interplay of Autonomy, Leadership Style, and Depressive Symptoms. Arch Psychiatr Nurs 2014; 28:160-6.

12. Akbari F, Tofighi S, Torabi A, Arab M, Tarahi M. Leadership style and conflict management in hospital managers in university of Lorestan medical sciences. Yafteh 2004; 7(2):51-9.

13. Al-Hamdan Z, Norrie P, Anthony D. Conflict management styles used by nurses in Jordan.J Res Nursing 2012; 19(1):40-53.

https://doi.org/10.1177/1744987112466085

14. Hassanian ZM, Rahrovan A, Shayan A, Farhadian M, Sadeghi A. The Relationship between Leadership Style of Head Nurses and Career Independence of Nurses in Educational Hospitals of Hamadan University of Medical Sciences. Int J Adv Res BiolSci 2017; 4(10): 110-5.

https://doi.org/10.22192/ijarbs.2017.04.10.015

15. Rad M, Shomoossi N, Rakhshani M H, Torkman Nejad Sabzevari M. Psychological Capital and Academic Burnout in Students of Clinical Majors in Iran.ActaFac Med Naiss 2017; 34(4):311-9. https://doi.org/10.1515/afmnai-2017-0035 


\title{
Odnos između stila liderstva i rešavanja konflikta između medicinskih sestara u obrazovnim i zdravstvenim centrima
}

\author{
Zahra Marzieh Hassanian¹, Amir Sadeghi², Maryam Farhadi³, Amanj Rahrovan ${ }^{4}$ \\ ${ }^{1}$ Univerzitet medicinskih nauka u Hamadanu, Fakultet za sestrinstvo i akušerstvo, Departman za sestrinstvo, \\ Hamadan, Iran \\ ${ }^{2}$ Istraživački centar za negu majke i deteta, Univerzitet medicinskih nauka u Hamadanu, Hamadan, Iran \\ ${ }^{3}$ Istraživački centar za modelovanje nezaraznih bolesti, Univerzitet medicinskih nauka u Hamadanu, Hamadan, Iran \\ ${ }^{4}$ Bolnica Bu-Ali, Oblast Marivan, Kurdistan, Iran
}

\section{SAŽETAK}

Liderstvo je sredstvo i potencijalna snaga jedne organizacije. Korišćenjem adekvatnog stila liderstva, menadžeri bi mogli da dostignu organizacione ciljeve i reše konflikte na mnogo efikasniji način. Cilj ove studije bio je da se ispita odnos između stilova liderstva i rešavanja konflikta između medicinskih sestara zaposlenih $u$ obrazovnim i zdravstvenim centrima u gradu Hamadanu.

Za izvođenje studije korišćene su deskriptivne i korelacione procedure. Korišćenjem metode stratifikovanog slučajnog uzorkovanja, izabrano je 240 medicinskih sestara iz obrazovnih i zdravstvenih centara. Za prikupljanje podataka koji se odnose na stilove liderstva i rešavanje konflikta, korišćeni su dvostandardni upitnici. Podaci su analizirani pomoću SPSS softvera (verzija 16) i korišćenjem testova poput Parsonovog testa i Kruskal-Wallis testa.

Najčešći tip upravljanja kod medicinskih sestara bio je demokratski tip (94,6\%), dok su direktivni stil i kombinovani pristup primenjivani u samo 2,5\% i 2,9\% slučajeva. Štaviše, najbiranija strategija rešavanja konflikta bila je neinterventna strategija $(50,15 \pm 10,34)$, nakon čega sledi strategija orijentisana ka nalaženju rešenja (38.65 \pm 7.31$)$ i strategija usmerena ka uspostavljanju kontrole $(27,04 \pm 3,61)$. Ustanovljena je značajna povezanost između stila liderstva i strategije rešavanja konflikta $(\mathrm{p}<0,001)$.

Utvrđeno je da je kod rešavanja konflikta stil liderstva u značajnoj i pozitivnoj korelaciji sa neinterventnom strategijom, kao i strategijom orijentisanom ka nalaženju rešenja. Za razliku od toga, odnos između stila liderstva i strategije usmerene ka uspostavljanju kontrole nije bio značajan. Usvajanje demokratskog stila liderstva, kao i kombinovane strategije preporučuje se menadžerima medinskih sestara u domenu rešavanja konflikta.

Ključne reči: stil liderstva, rešavanje konflikta, medicinska sestra, klinički i obrazovni centri 